\title{
MALA SMREKINA OSA LISTARICA (PRISTIPHORA ABIETINA CHRIST. 1791) - PRILOG POZNAVANJU BIOLOGIJE ŠTETNIKA U SVJETLU NOVONASTALIH ŠTETA
}

\section{SMALL SPRUCE LEAF WASP (Pristiphora abietina Christ. 1791) - CONTRIBUTION TO THE BIOLOGY OF PEST IN THE VIEW OF NEWLY DAMAGES}

\author{
Emsud SELMAN ${ }^{1}$, Mirza DAUTBAŠIĆ ${ }^{2}$, Osman MUJEZINOVIĆ ${ }^{2}$
}

\begin{abstract}
Sažetak
Utvrđivanje bionomije i utjecaja štetnika smrekine ose listarice, Pristiphora abietina na zdravstveno stanje šumskih kultura smreke provedeno je u sastojinama Šumskoprivrednog područja „Ključko“. Istraživanjem su procjenjivani i mjereni sljedeći parametri: početak, tok i kraj rojenja male smrekine ose listarice, biologija i tok nastajanja simptoma na napadnutim stablima smreke. Za ulov jedinki P. abietina korištene su žute, ljepljive, ploče. Svaka od serija za ulov imala je 10 ploča sa 20 ljepljivih površina. Ukupno je u 180 ljepljivih ploča, ulovljeno 2640 jedinki $P$. abietina, od toga 1903 mužjaka ili 72,1 \% i 737 ženki ili $27,9 \%$. Utvrđene su značajne štete uzrokovane ovim štetnikom na istraživanom području.
\end{abstract}

KLJUČNE RIJEČI: Hymenoptera, Tenthredinidae, žute ljepljive klopke, bionomija, oštećenje iglica.

\section{UVOD}

\section{INTRODUCTION}

U kulturama smreke, kao i u prirodnim sastojinama zapadne, centralne i istočne Europe štete od smrekine ose listarice Pristiphora abietina Christ. 1971 (Hymenoptera, Tenthredinidae) (sin. Nematus abietum Hartig, 1834) su poznate već preko 130 godina. Najznačajnije su, nastale iza Drugog svjetskog rata, a iza toga sa smanjenim intenzitetom traju do danas. U Bosni i Hercegovini, štetnik je prvi put okriven 1976. godine u šumskim kulturama smreke u blizini Travnika, a ubrzo potom guste populacije nađene su i na drugim lokalitetima, u okolici Banja Luke, Tarčina i Tjentišta. Iako štete nikada nisu u potpunosti prestale, nakon tog perioda postale su mnogo manje, jer se od 1980. godine prilikom izrade Šumskogospodarskih osnova posebna pozornost poklanjala šumsko-uzgojnim radovima, najviše pošumljavanju, odnosno zahtjevima pojedinih vrsta prema uvjetima staništa.

Pristiphora abietina je vrsta koja je u Europi prilično dobro proučena i o njenoj biologiji i štetama koje prouzrokuje su napisani mnogobrojni znanstveni i stručni radovi, dok ih na prostoru Bosne i Hercegovine nema. Oskudni domaći

\footnotetext{
1 Mr. sc. Emsud Selman, ŠPD „Unsko-sanske šume“ d.o.o., Bosanska Krupa, Šumarija Ključ, Bosna i Hercegovina, e-mail: emselkljuc@gmail.com

${ }_{2}^{2}$ Prof, dr. sc. Mirza Dautbašić, e-mail: mirzad@bih.net.ba, Prof. dr. sc. Osman Mujezinović, e-mail:osmansfs@yahoo.com, Šumarski fakultet Univerziteta u Sarajevu, Katedra za zaštitu šuma, urbaog zelenila i lovnog gopspodarenja, Zagrebačka 20, 71000 Sarajevo, Bosna i Hercegovina
} 

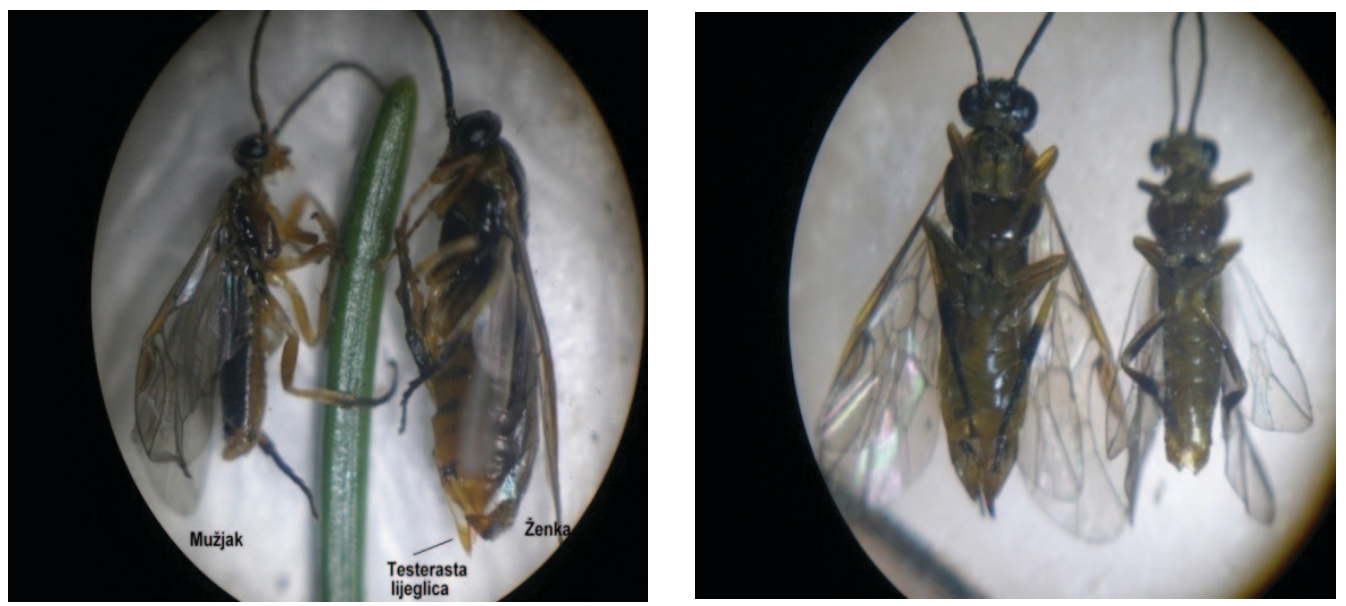

Slika 1 i 2: Imaga Pristiphora abietina (ventralno)

Picture 1 and 2: Adults of Pristiphora abietina (ventral)

radovi o ovom štetnom insektu i sporadična pojava u šumskim kulturama uzrok su njegovom zaboravljenom štetnom potencijalu.

Nakon kalamiteta u kulturama od 1887. - 1895. godine (Kurir, 1982) u Europi, ovaj je insekt predmetom proučavanja i izrade mnogobrojnih znanstvenih radova. Od tada do danas povremeno se javljaju kalamiteti koji govore o ogromnim štetama u kulturama smreke, ponekad do te mjere da su uništeni cijeli šumski kompleksi.

Ženke štetnika su dužine 5 do $6 \mathrm{~mm}$, uglavnom su crne, dok su neki dijelovi žućkaste boje (slika 1 - 4). Noge su također uglavnom žućkaste, ali s manjim crnim područjima. Mužjaci su 4 do $5 \mathrm{~mm}$ (slika 1 - 4), žućkasti sa crnim područjima dijela čela, tjemena i zadnjeg dijela glave, zatim srednje grudi i gornja strana trbuha. Mužjaci brže lete i pokretljiviji su u prostoru od ženki.

Jaja su neposredno nakon polijeganja staklasto prozirna, sa nježnom elastičnom opnom $0,8-1,2 \mathrm{~mm}$ duga i $0,4-0,5$ $\mathrm{mm}$ široka (Holuša, 1999). Tijekom embriogeneze postaju prljavo bijela. Razmnožavanje se odvija gamogenezom i partenogenezom. Ženka polaže 80 do 100 jaja. Iz oplođenih se razvijaju nove ženke, a iz neoplođenih jaja samo mužjaci (Pschorn - Walcher, 1982). Nakon što testerastom legali- com u nježnom tkivu iglice zasiječe uzdužni zarez, ženka u njega utisne jaje do polovine njegove širine. Na jednoj iglici nalazi se samo jedno jaje, dok ih u izbojku može biti i do 15, najčešće 4 - 6 (slika 5 i 6).

Larve građom liče na gusjenice leptira, pa se nazivaju pagusjenice (imaju 7 pari lažnih trbušnih nogu). Tijelo im je crvoliko, valjkasto izduženo, uglavnom golo prema zadnjem kraju nešto suženo. U početku su svijetlozelene, skoro prozirne a kasnije zelene kao i iglice kojima se hrane. $\mathrm{Na}$ bočnim stranama sa tamnozelenim bradavičastim ispupčenjima koja nose grupice svijetlih dlačica. Glava je svijetložuta do crvenkasta, sa upadljivo crnim bočnim očima. Na glavi se nalazi jedno tačkasto oko. Prsne noge su svijetlije od tijela, staklasto su prozirne. Na trbuhu je sedam pari lažnih zelenkastih nogu, raspoređenih na 2. 7. i 10. segmentu (slika 7 i 8). U toku razvoja larva prolazi kroz četiri (mužjaci) odnosno pet (ženke) larvalnih stadija (Lorenz - Kraus, 1957.). Hrane se isključivo mladim iglicama svibanjskih izbojaka. Po završetku ishrane larva pada u stelju ispod stabala, gdje plitko u zemljištu ispreda sklonište - pergamentirani kokon. U njemu se prvo presvuče u eonmfu i tako prezimi, a onda u pronimfu koja se potom preobrazi u lutku.
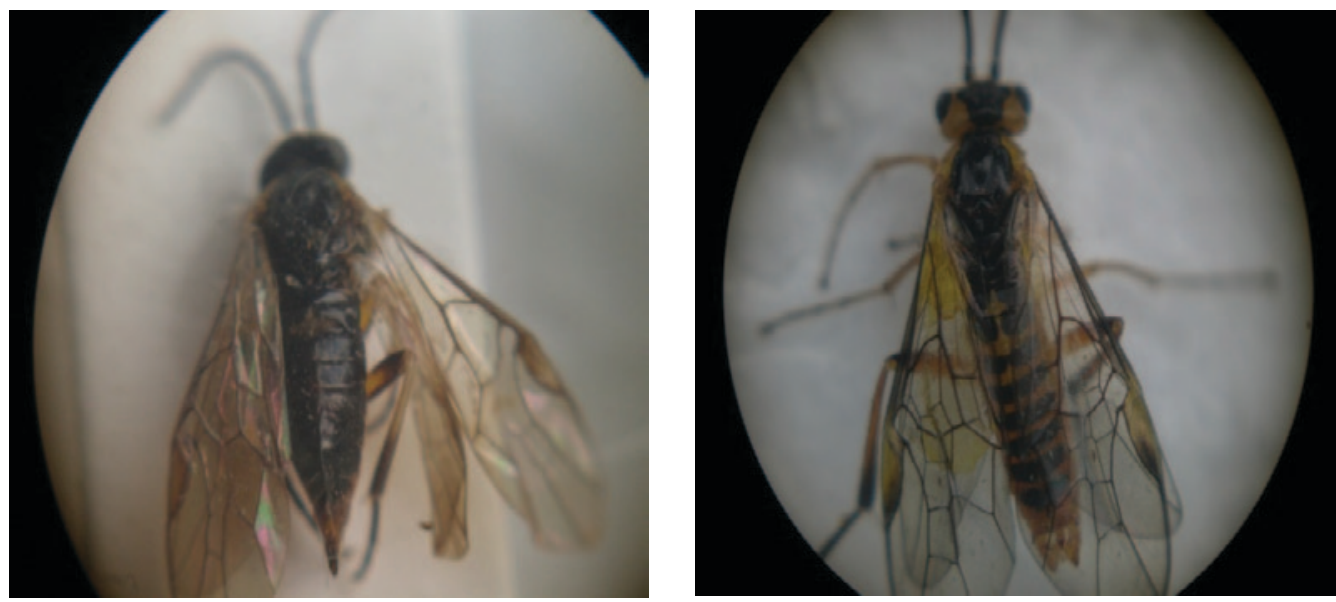

Slika 3 i 4: Imaga ženke i mužjaka Pristiphora abietina (dorzalno)

Picture 3 and 4 : Female and male adults Pristiphora abietina (dorsal) 
Slika 5 i 6: Ženka Pristiphora abietina pri polaganju jaja i položena jaja na iglicama smrče

Picture 5 and 6: Female of Pristiphora abietina while laying eggs, and the deposited eggs on the needles of spruce
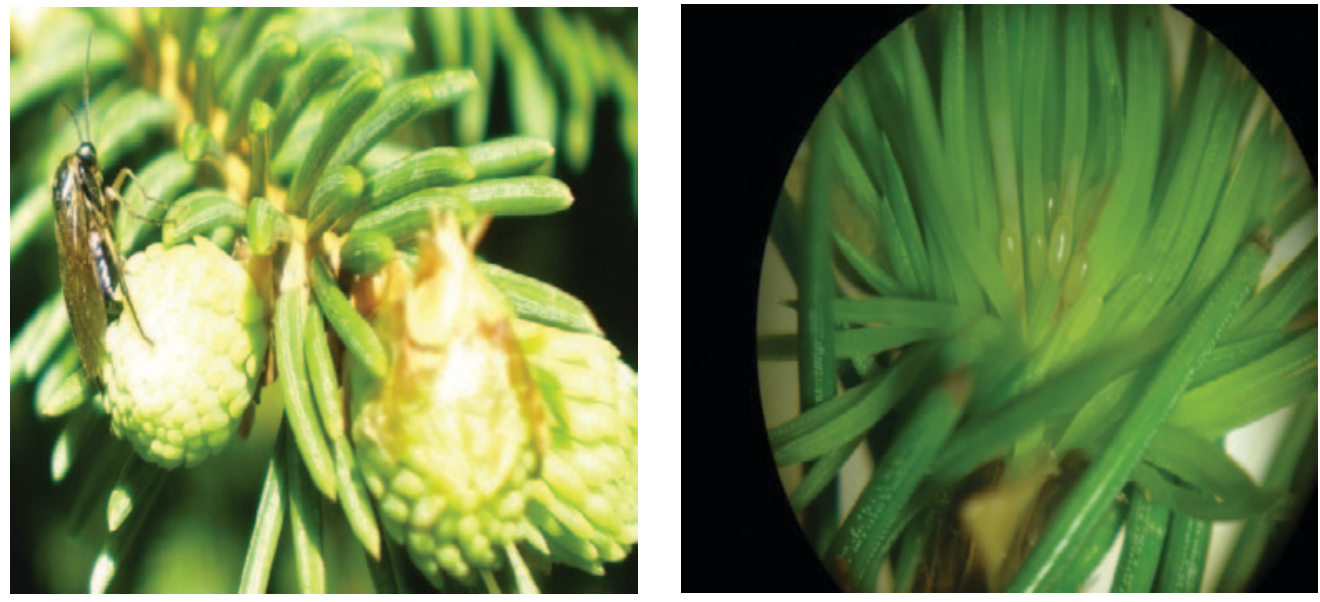

Eonimfa nastaje tijekom ljeta presvlačenjem pagusjenice u pergamentiranom kokonu. Ona je nešto manja od pagusjenice, srpasto povijenog položaja tijela i tamno zelene boje, sa bočnim očima upadljivo crnim. Grudni dio je znatno širi od trbušnog koji se sužava prema kraju. Prsne noge su boje tijela, jasno razvijene dok su trbušne zakržljale i u obliku su malih bradavica. U odnosu na pagusjenicu eonimfa ima drukčije šare po tijelu (Pschorn - Walcher, 1982). Na tjelesni nadražaj reagira srpastim uvijanjem ili okretanjem oko svoje ose, ali pokreti nisu koordinirani, te se nije u stanju kretati (slika 9). Vrsta u ovom razvojnom stadiju pada u dijapauzu i prezimljuje u svom kokonu, a potom se početkom proljeća presvuče u pronimfu. Jedan dio eonimfi 10-20\% može i do pet godina ostati u dijapauzi prije nego se u proljeće presvuče u pronimfu (Pschorn - Walcher, 1982).

Pronimfa nastaje početkom proljeća presvlačenjem eonimfe, zadržava izgled i veličinu eonimfe. Razlike se uočavaju kod zrelih pronimfi po nastanku svijetlije središnje mrlje u do tada tamnim očima i po nastanku zatamnjenih zona na mjestima gdje će nastati lutkine oči. Tijelo postaje zdepastije, prsne noge se priljubljuju uz tijelo, a trbušne se resorbiraju (Pschorn - Walcher, 1982) (slika 10).
Slobodna kukuljica (pupa libera) nastaje preobrazbom pronimfe. Na njoj se mogu razlikovati svi vanjski dijelovi imaga. U početku su žutobijele boje, a kasnije se ispod mekane prozirne košuljice kukuljice počinju ukazivati tamnije zone, prvo tamo gdje će biti oči imaga, pa zatim glava (Olenici - Olenici, 2005) (slika 11). Spolovi se ne naziru.

Kokoni su izduženo ovalne forme, s obje strane pravilno zaobljeni ispredeni od vrlo čvrstih pergamentiranih niti. Boja kokona i elastičnost zavisi od vlažnosti sredine. Ako je vlažnost stelje veća, kokoni su tamniji. U početku, nakon ispredanja su hrđavocrvene, a kasnije tamnosmeđe do sive boje. Kokoni ženki su u načelu nešto veći od kokona mužjaka. Isti se nalaze $3-5 \mathrm{~cm}$ u rastresitom sloju zemljišta. $\mathrm{Na}$ ovaj način insekt provede u svom kokonu cijelih 10 mjeseci.

Uslijed napada gornja polovica krošnje jako se prorijedi, prošlogodišnji izbojci su bez iglica ali živi znatno kraći, dok su vršni mnogobrojni (viševrhost i grmoliki) (slika 12). Oštećeni izdanci najvećim dijelom ponovo propupaju i prolistaju. Samo oni napadnuti nekoliko godina uzastopno se osuše. Ispiljene pagusjenice se hrane isključivo mladim iglicama, prvo izgrizaju iglicu na kojoj su se ispilile. U početku golobrsta simptomi napada su u formi grizotina i početnog žućenja te crvenila iglica oko oštećenja. Također, može se
Slika 7 i 8: Larve Pristiphora abietina prilikom ishrane i larve različitih stadija razvića Picture 7 and 8: Larvae of Pristiphora abietina during feeding and different stages of development
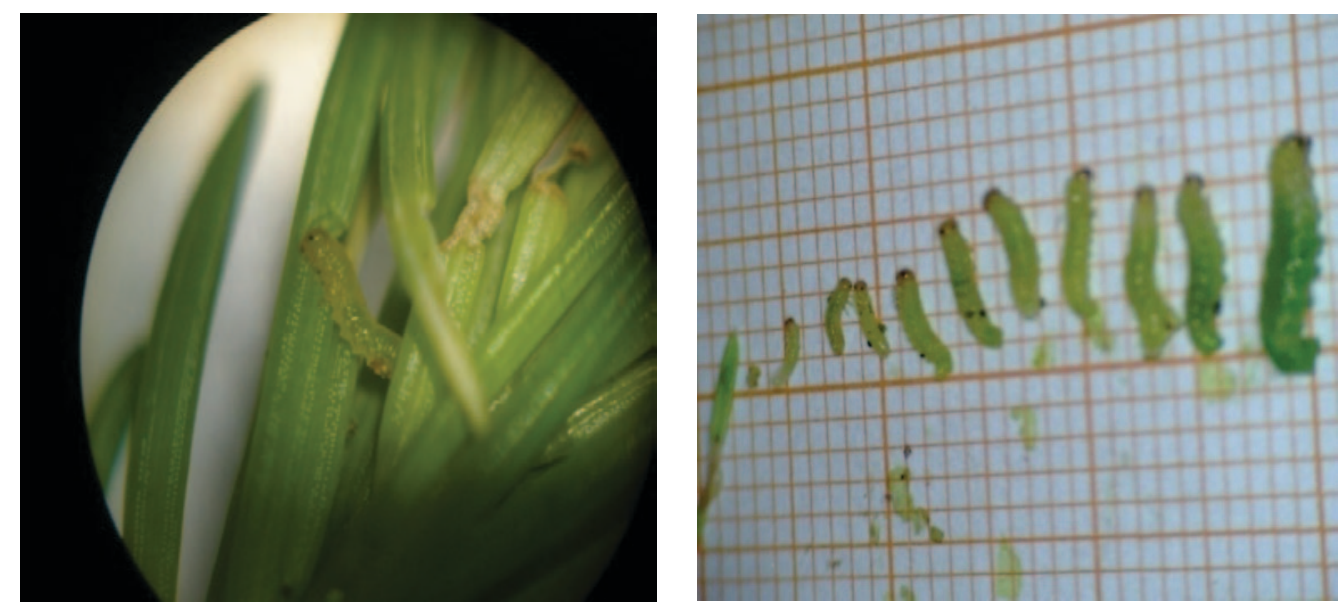

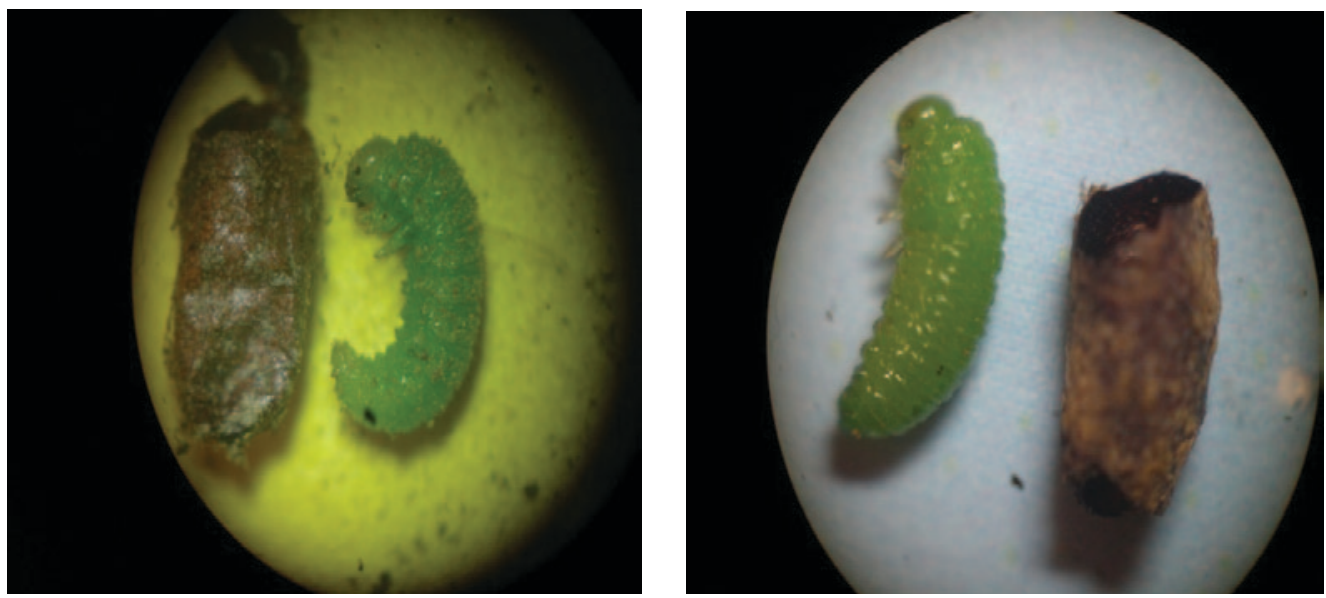

Slika 9 i 10: Eonimfa Pristiphora abietina u kokonu pred prelazak u pronimfu i pronimfa

Picture 9 and 10: Eonimf Pristiphora abietina in a cocoon before turning to pronimf and pronimf

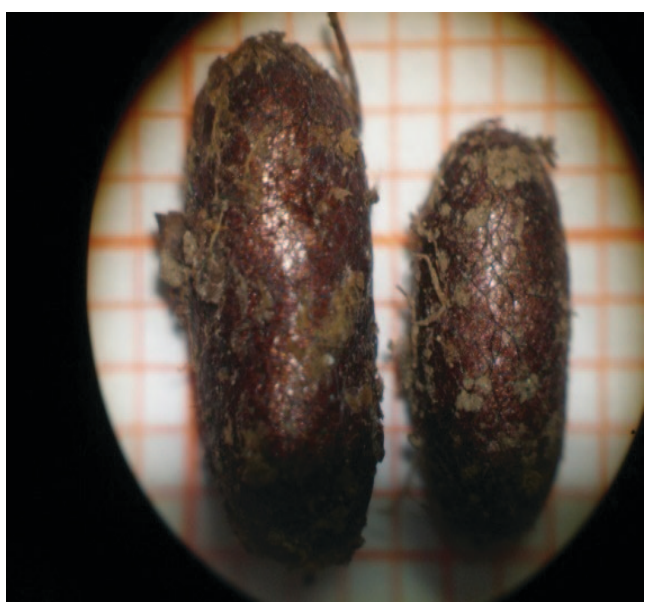

Slika 11: Kokon Pristiphora abietina mužjaka i ženke Picture 11: Kokon of Pristiphora abietina, male and female

uočiti sušenje i savijanje napadnutih iglica, ali se isto ne primijećuje iz daljine. Nakon 15 - 20 dana vrhovi stabala i bočni izdanci poprimaju crvenkastu, a pozom hrđavocrvenu boju (slika 13). Prilikom ishrane odlomljeni nepojedeni dijelovi iglica padaju s grana, i u slučaju jačeg napada pri toplom i mirnom vremenu može se čuti šum koji nastaje grickanjem i padanjem velikog broja odgriženih nepojede- nih dijelova te ekskremenata. S vremenom crvenkaste iglice poprimaju sivocrvenu boju te otpadaju sa stabla.

Prilikom jačeg pljuska, sve odgrižene i više oštećene iglice voda ispere sa grana pa nestaje crvenila krošanja, a javlja se prorijeđenost tj. uočava se nedostatak iglica. $S$ obzirom da se radi o asimilacijskom aparatu koji biljci osigurava gradivne materije, njegov nedostatak izaziva umanjenje visinskog i zapreminskog prirasta stabla. Napadnuto stablo gubi 26-38\% zapreminskog prirasta u godini jačeg napada i još $11 \%$ tijekom nekoliko godina nakon toga (Klemt i drugi, 2009). Prema Holuša i Lubojacký (2007) smrekina osa listarica je opasan štetnik koji utječe na destabilizaciju zdravstvenog stanja šuma četinjača u svim europskim zemljama. Uzastopni golobrsti od nekoliko godina uzrokuju sušenja vrhova i na kraju cijelog stabla. Također, štetno djelovanje je jače izraženo na stablima koja rastu na mjestima izvan prirodne granice rasprostranjenja (Holonec i drugi, 2004).

\section{PODRUČJE I METODE ISTRAŽIVANJA RESEARCH AREA AND METHODS}

Predmetna šumska kultura smreke nalazi se u području sjeverozapadne Bosne, 8 km sjeverno od grada Ključa, na
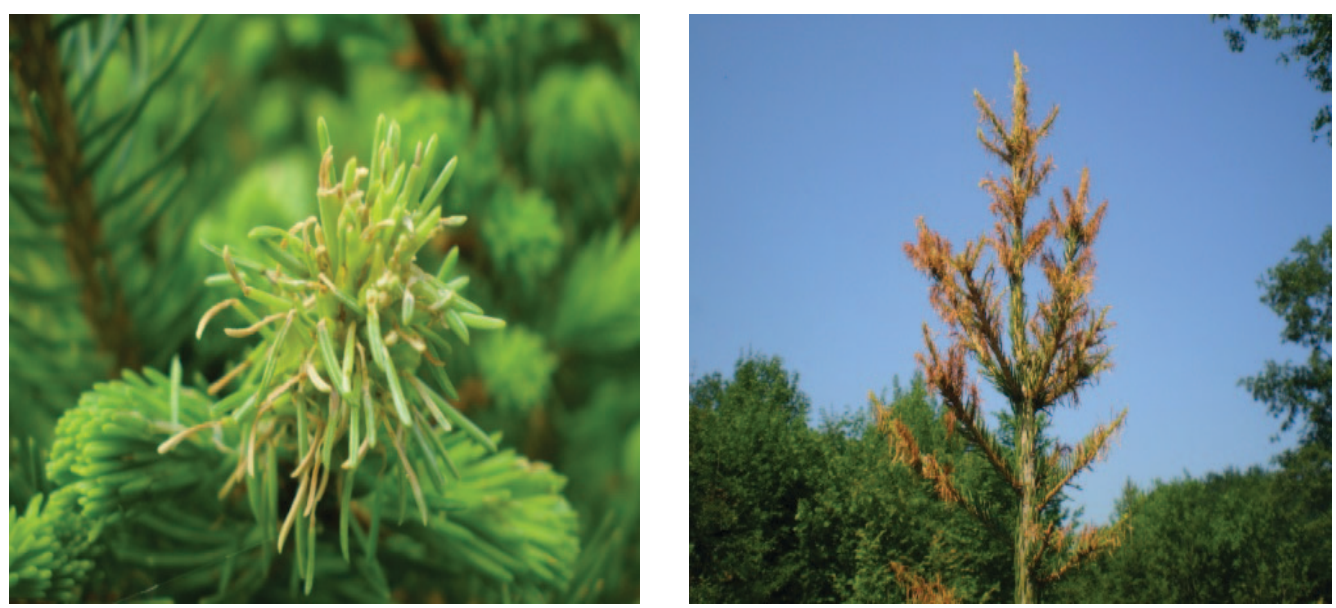

Slika 12 i 13: Simptomi napada Pristiphora abietina

Picture 12 and 13: Simptoms of attack Pristiphora abietina 
Slika 14 i 15: Odabrano stablo sa postavljenom ljepljivom pločom za Pristiphora abietina i praćenje silaska pagusjenica u tlo

Picture 14 and 15: The selected tree with the established sticky plate for Pristiphora abietina and monitoring of the descent of caterpillar into the soil
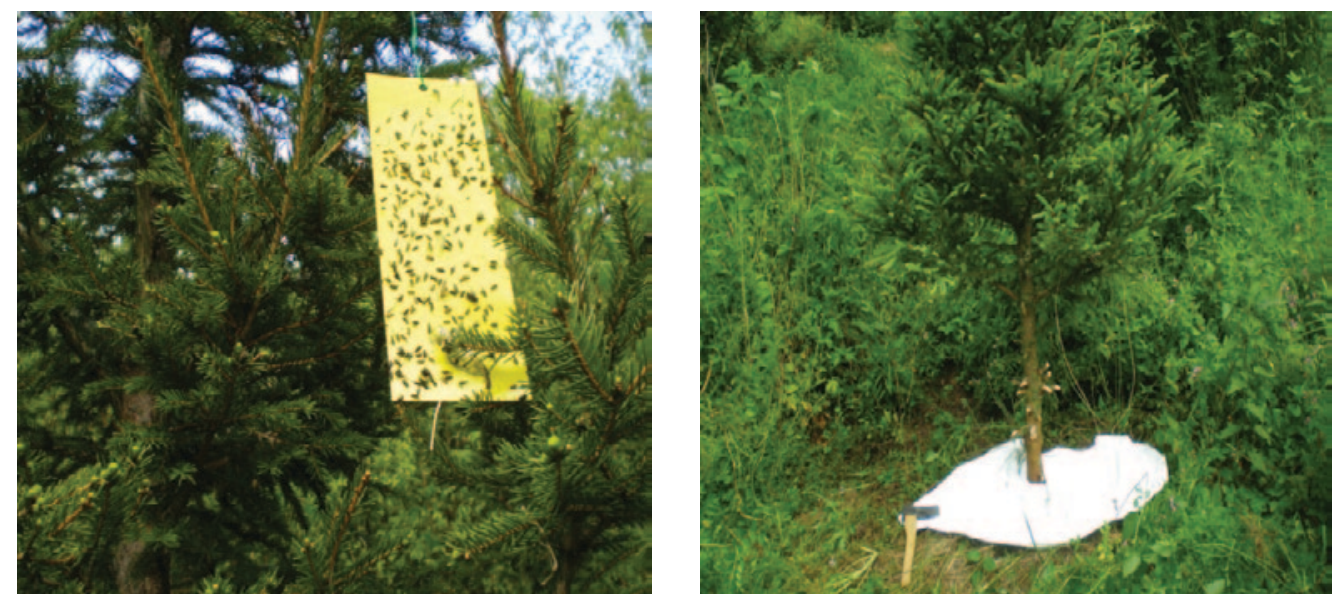

području Šumskoprivrednog područja „Ključko“, u sastavu odjela 27, gospodarske jedinice „Ošljak-Golaja“. Geokoordinate su: S 44 $35^{\prime} 53^{\prime \prime}$, I 1 16 $47^{\prime} 12^{\prime \prime}$, nadmorska visina 450 do $480 \mathrm{~m}$. Prema ŠGO ovaj šumski zasad pripada šumskim kulturama smreke na pretežito dubokom vapnencu. Površina istraživanog objekta je 22,5 ha.

Odsjek „a“ - šumska kultura smreke, nastala je izravnom konverzijom - čistom sječom jednog dijela odjela 27 lošije izdanačke šume bukve u razdoblju od 1998. - 2000. godine. Ukupan broj zasađenih sadnica smreke iznosio je 69550.

Šumska kultura je do 2011. godine bila dobrog zdravstvenog stanja, te nije bilo značajnog sušenja, osim pojedinačnih šteta uzrokovanih nekim štetnicima (npr. Sacchipanthes sp. i Adelges sp.).

Uz korištenje pristupačnih i pogodnih sredstava u uvjetima šumske kulture utvrđivala se: biologija vrste, period golobrsta i tok nastajanja simptoma na napadnutim stablima te dovođenja u vezu s uzrocima prenamnoženja.

Istraživanja štetnika podrazumijevala su i zapažanja u obliku digitalnih snimaka, uz konzultacije radova drugih autora (Schedl, 1953; Lorenz - Kraus, 1957; Brauns, 1970; Kurir, 1982; Schmied - Fuerer, 1996; Holuša, 1999, 2007).

Za ulov jedinki P. abietina korištene su žute, ljepljive ploče (veličine 10x25,8cm), (Aerexon Insect Control GmbH, Waiblingen - D), koje inače služe za ulov insekata u voćarstvu (slika 14). Ljepljive ploče su postavljane na prošlogodišnjim napadnutim stablima, u dužini $350 \mathrm{~m}$ i razmaku $25 \mathrm{~m}$. Iste su mijenjane svaka tri dana do završetka rojenja. Nakon skidanja, pod binokularom je obavljen pregled i evidencija uhvaćenih jedinki P. abietina prema spolu imaga.

Za mjerenje dužine tijela najkrupnijh larvi primijenjena je metoda skeniranja 1:1, uz pomoć softvera Autocad $2010 \mathrm{za}$ sve larvene stadije. Determinacija je rađena prema ključu za Pristiphora vrste (Wong, 1975). Svaka od 18 serija imala je 10 ploča sa 20 ljepljivih površina. Ukupno je upotrijebljeno 180 ljepljivih ploča.
$\mathrm{U}$ doba prestanka ishrane i prelaska pagusjenica u tlo ispod napadnutih stabala postavljane su bijele platnene podloge radi praćenja vremena silaska pagusjenica u zemljište (slika 15).

Usvrhu praćenja polaganja jaja, razvoja i rasta pagusjenica, svaki treći dan, kada su mijenjane ljepljive ploče, uzimani su uzorci izbojaka radi praćenja razvojnih stadija.

Radi povremenog praćenja temperature i vlage zemljišta (humusni sloj u kojemu se nalaze kokoni) i uporedbe podataka temperature zraka u kulturi sa podacima iz Meteorološke stanice Sanski Most, korišteni su usporedni digitalni i živin termometar. Radi lakšeg razumijevanja odvijanja životnih procesa vrste u prirodi, postavljen je prateći pokus od tri kutije - atrijuma u laboratoriji koji su sadržavali svježu grančicu smreke sa tek otvorenim pupovima na koje su donesena imaga mužjaka i ženki. Grančice su bile postavljene u posude s vodom, a ispod odvojeno je postavljen humus debljine $8 \mathrm{~cm}$ koji je povremeno ovlaživan da bi se osigurali optimalni uvjeti razvoja jedinki u kokonu. U laboratorijskim uvjetima praćeno je polaganje jaja, vrijeme embrionalng razvoja i vrijeme izgradnje kokona.

\section{REZULTATI}

RESULTS

Na grafikonu 1 prikazan je ulov štetnika na području objekta istraživanja.

Ljepljivim klopkama ulovljeno je ukupno 2640 jedinki $P$. abietina, od toga 1903 mužjaka ili 72,1 \% i 737 ženki ili $27,9 \%$ (grafikon 1). Tokom pet serija (74 ljepljive ploče) nije bilo uhvaćenih imaga $P$. abietina, a to se odnosi na prvu seriju od 24.04. do 26.04. i četiri posljednje serije 05.06. do 16.06.

Na osnovi prikupljenih podataka o ulovu štetnika $P$. abietina, provedena je deskriptivna statistika, a s ciljem utvrđivanja osnovnih parametara ispitivanog statističkog skupa (tablica 1). 


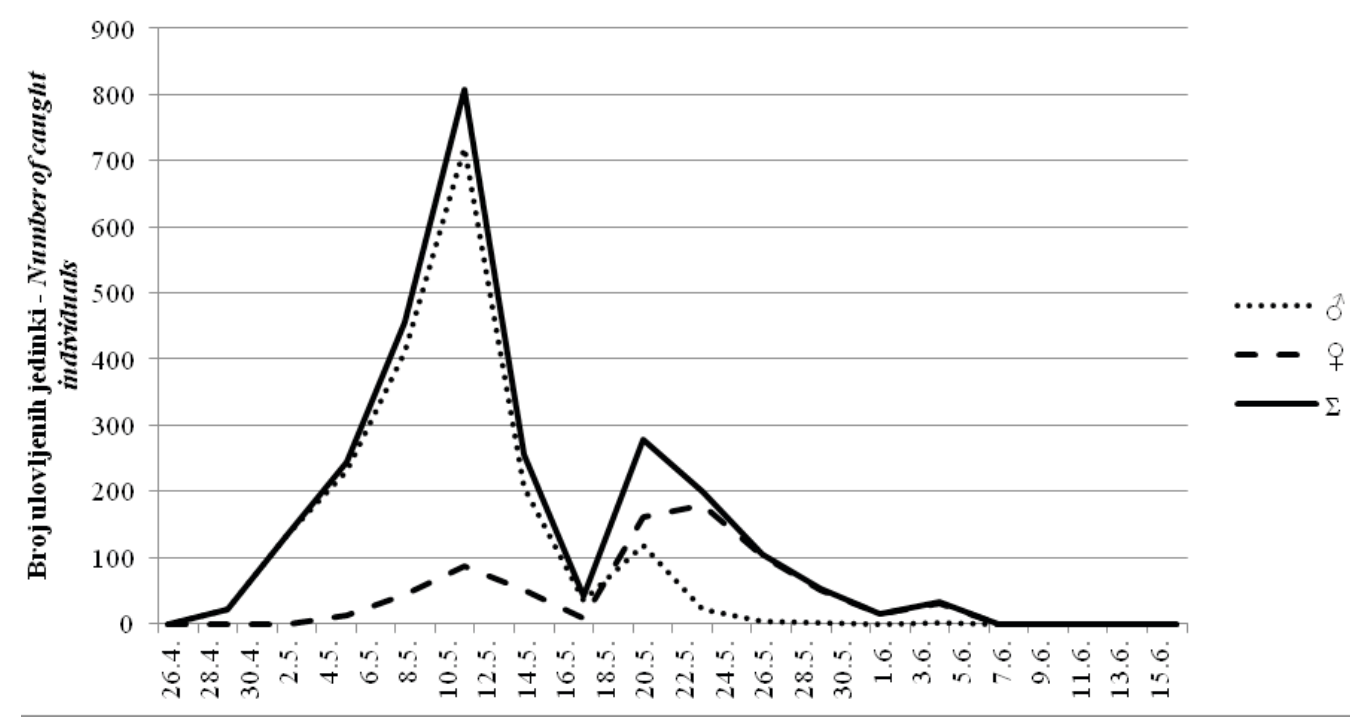

Grafikon 1: Ulov Pristiphora abietina u ljepljive klopke tokom 2014. godine

Figure 1: Catch of Pristiphora abietina in sticky traps in 2014

Tablica 1: Deskriptivna statistika za broj uhvaćenih jedinki Pristiphora abietina

Table 1: Descriptive statistics for the number of caught individuals of Pristiphora abietina

\begin{tabular}{|c|c|c|c|}
\hline \multicolumn{2}{|c|}{$\begin{array}{l}\text { Mužjak } \\
\text { Male }\end{array}$} & \multicolumn{2}{|c|}{$\begin{array}{l}\text { Ženka } \\
\text { Female }\end{array}$} \\
\hline $\begin{array}{c}\text { Aritmetička sredina } \\
\text { Mean }\end{array}$ & 105,72 & $\begin{array}{c}\text { Aritmetička sredina } \\
\text { Mean }\end{array}$ & 40,94 \\
\hline $\begin{array}{l}\text { Medijana } \\
\text { Median }\end{array}$ & 12 & $\begin{array}{l}\text { Medijana } \\
\text { Median }\end{array}$ & 13 \\
\hline $\begin{array}{l}\text { Mod } \\
\text { Mode }\end{array}$ & 0 & $\begin{array}{l}\text { Mod } \\
\text { Mode }\end{array}$ & 0 \\
\hline $\begin{array}{l}\text { Standardna devijacija } \\
\text { Standard deviation }\end{array}$ & 190,31 & $\begin{array}{l}\text { Standardna devijacija } \\
\text { Standard deviation }\end{array}$ & 56,12 \\
\hline $\begin{array}{l}\text { Varijansa } \\
\text { Variance }\end{array}$ & 36221,03 & $\begin{array}{l}\text { Varijansa } \\
\text { Variance }\end{array}$ & 3150,40 \\
\hline Minimum & 0 & Minimum & 0 \\
\hline Maximum & 720 & Maximum & 178 \\
\hline $\begin{array}{l}\text { Nivo pouzdanosti } \\
\text { Confidence level }\end{array}$ & $105,72 \pm 94,64$ & $\begin{array}{l}\text { Nivo pouzdanosti } \\
\text { Confidence level }\end{array}$ & $40,94 \pm 27,91$ \\
\hline
\end{tabular}

Podaci prosječnih dnevnih temperatura dobiveni su sa Meteorološke stanice Sanski Most, koja se nalazi nedaleko od objekta istraživanja. Nastojalo se utvrditi na koji način temperatura ima utjecaj na ulov ovog štetnika. Za priku-

Tablica 2: Dimenzije pojedinih razvojnih stadija Pristiphora abietina unutar objekta istraživanja

Table 2: The dimension of individual developmental stages of Pristiphora abietina inside the object of research

\begin{tabular}{|c|c|c|}
\hline $\begin{array}{c}\text { Razvojni stadij } \\
\text { Development stage }\end{array}$ & $\begin{array}{l}\text { Dužina }(\mathrm{mm}) \\
\text { Length }(\mathrm{mm})\end{array}$ & $\begin{array}{l}\text { Širina }(\mathrm{mm}) \\
\text { Width }(\mathrm{mm})\end{array}$ \\
\hline $\begin{array}{l}\text { Jaje } \\
\text { Egg }\end{array}$ & 1,0 & 0,3 \\
\hline $\begin{array}{l}\text { Larva } \\
\text { Larvae }\end{array}$ & $1,5-15,0$ & $2,0-2,8$ \\
\hline $\begin{array}{l}\text { Kokon } \\
\text { Pupae }\end{array}$ & $4,5-7,7$ & $1,9-3,4$ \\
\hline $\begin{array}{l}\text { Imago } \\
\text { Imago }\end{array}$ & $4,0-5,0$ & $1,0-1,5$ \\
\hline
\end{tabular}

pljene podatke izvršena je obrada regresijskom analizom (varijabla y - broj ulovljenih jedinki i varijabla - $\mathrm{x}$ (temperatura) (grafikon 2). Regresijskom analizom obuvaćene su samo one serije (13 serija) u kojima je utvrđen ulov jedinki.

Provedenom regresijskom analizom utvrđeno je da postoji pozitivna veza između broja ulovljenih jedinki i povećanja temperature $\left(R^{2}=0,005\right)$.

U Tablici 2 predstavljene su dimenzije pojedinih razvojnih stadija ovoga štetnika.

Tijekom jednogodišnjeg ciklusa, kontinuiranim uzimanjem kokona ispod napadnutih stabala i njihovom analizom (otvaranje kokona i pregled razvoja jedinke), pregledom napadnutih grančica (polaganje jaja, embriogeneza, larvalni razvoj) te analizom intenziteta ulova imaga, za vrijeme rojenja, pomoću ljepljivih klopki, napravljen je kalendar razvoja insekta za ŠGP „Ključko“ (slika 16). 
Grafikon 2: Regresijska analiza zavisnosti broja ulovljenih jedinki Pristiphora abietina i temperature u objektu istraživanja

Figure 2: Regression analysis of dependency of number of caught individuals of Pristiphora abietina, and the temperature in object of research

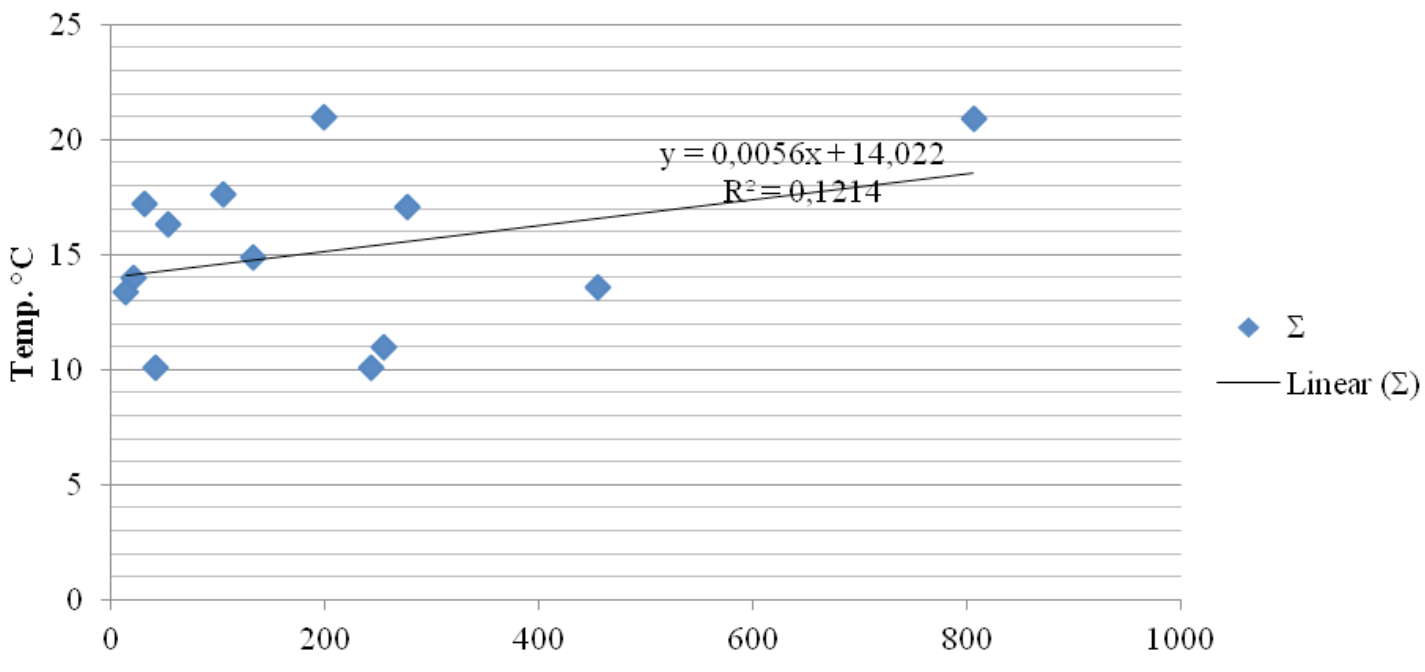

Broj ulovljenih jedinki $P$. abietina/ Number of caught individuals P.abiertina

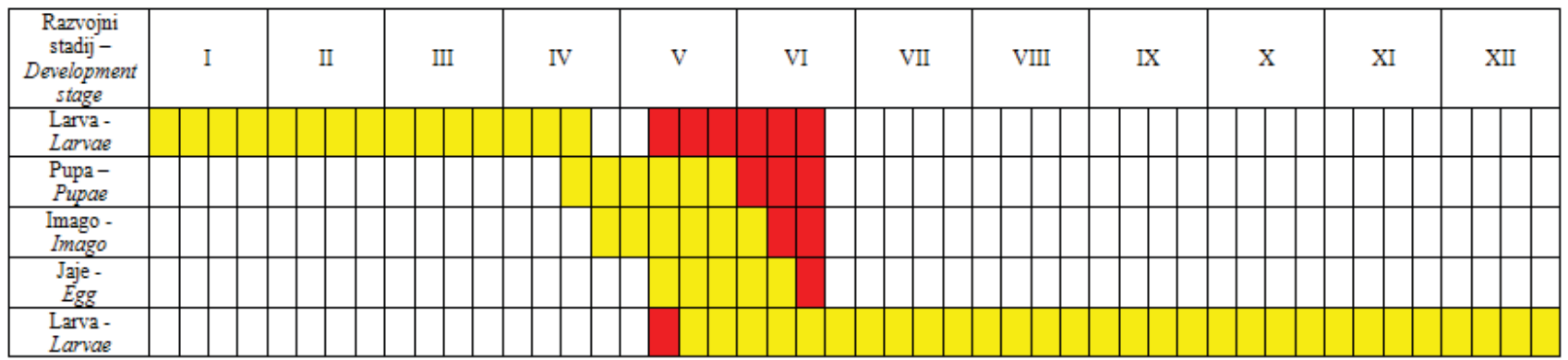

Pojava razvojne faze - The appear ance of developmental stages

Golobrst - Defoliation

Slika 16: Kalendar razvoja Pristiphora abietina u 2014. godini na oglednom lokalitetu Krasulje ŠPP „Ključko“ Picture 16: Calendar of development of Pristiphora abietina in 2014 at the experimental site Krasulje ŠGP „Ključko”

\section{RASPRAVA DISCUSSION}

Istraživanjima koja su provedena na području Zapadne Bosne, utvrđivana je bionomija i štetno djelovanje male smrekine ose listarice.

Holuša i drugi (2007) zaključili su da postoji veći broj ulovljenih mužjaka u odnosu na broj ulovljenih ženki P. abietina (56:44\%), što je utvrđeno i u ovom istraživanju (72:28\%).

Holuša i drugi (2006) navode da ukoliko se tijekom sezone na jednoj klopci (ljepljiva ploča dimezija 14,8 x $21 \mathrm{~cm}$ ) ulovi više od 19 ženki $P$. abietina, nastupit će velike štete za sastojinu, koju nazivaju stupnjem 6, što predstavlja potpunu defolijaciju mladih iglica. Prema rezultatima ovih istraživanja, gdje je zabilježeno 40,9 ženki po jednoj ljepljivoj klopci, potpuna defolijacija mladih iglica dogodila se samo u gornjoj polovini krošnje.

Veći broj ulova mužjaka objašnjava se i njihovim načinom života, odnosno kretanje u prostoru mužjaka i ženki. Mužjaci su puno aktivniji, lete na sve strane oko krošanja u po- trazi za ženkama, te jednostavnije dospijevaju na ljepljivu klopku, dok ženke više vremena provode polažući jaja i krećući se po grančicama tražeći pogodan, tek otvoren pup za tu aktivnost.

Prema rezultatima provedene analize utvrđeno je da postoji pozitivna veza između broja ulovljenih jedinki i povećanja temperature $\left(\mathrm{R}^{2}=0,005\right)$. Provedenim istraživanjem $\mathrm{u}$ ovom radu također su utvrđene dimenzije pojedinih razvojnih stadija štetnika (tablica 2). Dobiveni rezultati za veličinu jaja štetnika, slični su onim dobivenim od drugih autora (Holuša, 1999).

Mjerenjem dužine tijela najkrupnijh larvi na kraju posljednjeg stadija (mužjaci 4, ženke 5 stadijuma), utvrđena je veličina larvi koja je iznosila $11,8 \mathrm{~mm}$, što se podudara s podacima drugih istraživača (Olenici i Olenici, 2005).

$\mathrm{Na}$ osnovi mjerenja dužine kokona utvrđeno je da su vrijednosti iznosile 4,5 - 7,7 mm, a širine 1,9-3,4 mm. Dobiveni rezultati su nešto veći u odnosu na vrijednosti do kojih je došao Holuša (1999). Kokoni ženki su u nešto veći od kokona mužjaka (Kurir, 1982). Kokoni ovog štetnika 
nalaze se $3-5 \mathrm{~cm}$ u rastresitom zemljištu, ispod mahovine ili stelje. Prosječne veličine imaga kretale su se od 4,0 - 5,0 $\mathrm{mm}$, a širina od $1,0-1,5 \mathrm{~mm}$.

Tijekom jednogodišnjeg ciklusa, kontinuiranim uzimanjem kokona ispod napadnutih stabala i njihovom analizom (otvaranje kokona i pregled razvoja jedinke), pregledom napadnutih grančica (polaganje jaja, embriogeneza, larvalni razvoj) te analizom intenziteta ulova imaga, tijekom rojenja ljepljivim klopkama, napravljen je kalendar razvoja insekta za ŠGP „Ključko“ (slika 16).

Rojenju prvih mužjaka u travnju, prethodilo je ukupno osam dana sa srednjom dnevnom temperaturom od $15^{\circ} \mathrm{C}$. Na lokalitetu istraživanja vrijeme pojave imaga utvrđeno je 28. travnja. Kod ove vrste, a s obzirom na to da se prvo javljaju mužjaci (pojavili su se 28. travnja a ženke 5. svibnja), a ženke nekoliko dana kasnije, utvrđena je protandrija. Ova pojava je potvrđena i u radovima drugih autora (Brudea i drugi, 2006; Holuša i drugi, 2007, 1999). Prema njihovim podacima ista je trajala četiri, dok je u ovim istraživanjima to bilo 7 dana. Rojenje se završilo 5. lipnja, a pagusjenice su završile ishranu i napustile stabla do 16. lipnja. Rojenje je trajalo ukupno 37 dana. Slični rezultati utvrđeni su i za bionomiju ovog štetnika na području Češke (Holuša, 1999). Prema istom izvoru, za istraživanja provedena 1998. godine utvrđen je početak rojenja 27. travnja, a protandrija je trajala tri dana. Kulminacija rojenja mužjaka je bila 3. svibnja, dok se rojenje okončalo 27. svibnja i trajalo je 30 dana. Ženke su imale kulminaciju rojenja 9. svibnja, a završetak rojenja 2. lipnja, odnosno ukupno 31 dan. Prema Brudea i drugi (2006) istraživanjima bionomije ovog štetnika za područje Rumunjske koje je provedeno 2004. godine, utvrđen je početak rojenja 4. svibnja, sa protandrijom u trajanju 2 dana, kulminacija 18. svibnja, a završetak rojenja 8.lipnja, a ukupni period rojenja od 35 dana. Prva jaja su pronađena 8. svibnja, a polaganje traje do prestanka rojenja 8. lipnja.

Prema rezultatima istraživanja koja su rađena u laboratoriju, utvrđeno je da embrionalni razvoj traje 2,5 - 4,5 dana, u prosjeku tri, a što je utvrdio i Holuša (1999). Larveni razvoj trajao je u prosjeku 11 dana (kod mužjaka) do 16 dana (kod ženki), što je potvrđeno i od drugih autora (Holuša, 1999).

U sastojini smreke, pokusna površina Krasulje, prve larve su se ispilile 8. svibnja, što znači da je za ženke prije polaganja jaja kopulacija i ishrana trajala tri dana. Posljednje pagusjenice su završile ishranu 16. lipnja, što znači da je larvalni razvoj populacije trajao 38 dana. Ovaj period prema istraživanjima Holuša i Švetska (2000) je trajao 25 dana. Na ovu razliku su vjerojatno utjecale klimatske prilike područja istraživanja.

Prve odrasle larve koje su dospjele u podlogu (na dubinu 3 $-5 \mathrm{~cm}$, utvrđene su pregledom bijele platnene podloge) radi izgradnje kokona i daljnjeg razvoja registrirane su 23. svibnja. U laboratoriju je utvrđeno da ispredanje kokona traje prosječno pet dana. Prva eonimfa na pokusnoj plohi je zabilježena 23. lipnja. U stadiju eonimfe insekt pada u dijapauzu i tako provede ostatak ljeta, jesen i zimske hladne, nepovoljne uvjete sredine. Prema Pschorn - Walcher (1982) jedan dio eonimfi $(10-20 \%)$ može i do pet godina ostati u dijapauzi prije nego se u proljeće presvuče u pronimfu. Prema Holuša i drugi (1999) ovaj broj iznosi svega oko $1 \%$. S obzirom na dužinu ovog istraživanja, ne može se razmatrati pokazatelj dijapauze. Eonimfa se nakon prolaska hladnih zimskih dana i pojavom nešto toplijih dana već krajem ožujka iz dijapauze preobrazi u pronimfu (prva pronimfa zabilježena je 21. ožujka). Početkom travnja javljaju se kukuljice (prva je zabilježena 7. travnja). Imaga su se pojavila već pred kraj travnja (prvi imago - mužjak registriran je 22. travnja).

Štetno djelovanje male smrčine ose ogleda se u oštećenju iglica, što uzrokuje prorijeđenost krošanja ili potpunu defolijaciju, umanjenju vitalnosti stabala, pojavu viševrhosti kao posljedicu oštećenja terminalnog izbojka, te znatan gubitak u prirastu drvne mase i tehničkom svojstvu stabala. Prema Holonec i drugi (2004), štetno djelovanje jače je izraženo na stablima koja rastu na mjestima izvan prirodne granice rasprostranjenja. Upravo ovaj zaključak i činjenica da je smreka na objektu istraživanja izvan prirodnog rasprostranjenja, može objasniti pojačano štetno djelovanje $P$. abietina. S toga se nameće kao imperativ za šumarske stručnjake posebna pozornost kod unošenja smreke na određenim staništima, te provođenje monitoringa u sastojinama koje su potencijalno ugrožene.

\section{ZAKLJUČCI}

\section{CONCLUSIONS}

Prema ciljevima i zadacima istraživanja u ovom radu utvrđena je bionomija i štetno djelovanje vrste P. abietina na stablima smreke. Na osnovi rezultata može se zaključiti sljedeće:

- Kod monitoringa populacije potrebno je uspostaviti korelaciju između ulova ljepljivim klopkama i broja kokona u tlu;

- Broj uhvaćenih mužjaka je bio 2,5 puta veći od broja ženki; - Rojenje mužjaka štetnika trajalo je 37, a ženki 30 dana;

- Larvalni razvoj populacije je trajao 38 dana.

\section{LITERATURA}

REFERENCES

- Brauns, A. (1970): Taschenbuch der Waldinsekten, Gustav Fischer Verlag, Stuttgart.

- Brudea, V., Pei, G. (2006): Bioecology and control researches concerning the little spruce sawfly (Pristiphora abietina) (Hymenoptera, Tenthredinidae), „Ştefan cel Mare” University, Faculty of Silviculture, Suceava, Romania. 
- Holonec, L., Cherechesiu, V., Taut, I. (2004): Research regarding the presence of the deleterious agent Pristiphora abietina in the pine arbors outside the specific spreading area, Bulletin U.S.A.M.V. Cluj-Napoca, Horticulture, 61: 127-132.

- Holuša, J. (1999): Bionomie pilatky smrkové (Hymenoptera: Tenthredinidae) naseverní Moravě a ve Slezsku v letech 199899, Zprávy Lesnického Výzkumu, 44 (4):19-27.

- Holuša, J., Drápela, K. (2006): Yellow sticky boards: a possible way of monitoring littlespruce sawfly (Pristiphoraabietina) (Hymenoptera:Tenthredinidae). Journal of Forest Science, 52, 2006 (1): pp. 13-21.

- Holuša, J., Lubojacký, J. (2007): Correlation between flight activity of sawflies Pristiphoraabietina, $P$. saxesenii, P. gerulaand $P$. leucopodia (Hymenoptera: Tenthredinidae) and spruce (Picea abies) bud breaking in Eastern Czech Republic. Journal of Forest Science, 53 (Special Issue): pp. 69-73.

- Klemmt, H.J., Dauber, E., Leibold, E., Radike, W.-D., Pretzsch, H. (2009): Auswirkungen des Befalls der Kleinen Fichtenblattwespe auf das Wachstum der Fichte. AFZ-Der Wald 23: 12471249.

- Kurir, A. (1982): Zur problematik des Massenauftretens der Kleinen Fichtenblattwespe in Oberösterreich. Öko-L 4/2: 9-13, 1982.
- Lorenz, H.; Kraus, M. (1957): Die Larval systematik der Blattwespen (Tenthredinidae und Megalodontoidea). Deutsche Akademie der Wissenschaften zu Berlin, 1957.

- Olenici, N.; Olenici, V. (2005): Pristiphora abietina (Christ) (Hymenoptera, Tenthredinidae) an important insekt pest of Norway spruce planted out of its natural area, Revista Paduriilor 01/2005, 120(1): 3-13

- Pschorn-Walcher, H. (1982): Unterordnung Symphyta, Pflanzenwespen, Die Forstschadlinge Europas 4:4-196, P. Parey, Hamburg und Berlin

- Savez inženjera i tehničara šumarstva i industrije za preradu drveta Jugoslavije (1981): Priručnik Izvještajne i dijagnostičko prognozne službe zaštite šuma, Beograd.

- Schedl, K. E. (1953): Die kleine Fichtenblattwespe (Lygaeonematus pini Retz.), Forstliche Bundesversuchsanstalt, Mariabrunn, s 180,1953.

- Schmied, A., Fohrer, E. (1996): Zur Bedeutung von Laufkäfern (Coleoptera, Carabidae) in Schadgebieten der Kleinen Fichtenblattwespe, Pristiphora abietina (Hymenoptera: Tenthredinidae), Entomol. Gener. 21(1): 081-094; Stuttgart.

- Wong, H. R. (1975): The abietina group of Pristiphora (Hymenoptera: Tenthredinidae). Can. Ent. 107:451-463.

\section{Summary}

Determining the impact of pest P. abietina on the health of the forest of spruce plantations was conducted in the area of the Forest area "Ključko" within the department „27“ forest management unit „Ošljak-Golaja“. Within the object of research assessed and measured the following parameters: the start, the course and the end of swarming of small spruce leaf wasp; biology of species; flux emergence of symptoms in the attacked trees spruce. To capture - catch specimens P. abietina were used yellow sticky traps for insects. Each series (18 series) had 10 with 20 traps sticky surface. A total of 180 used sticky traps. Caught a total of 2,640 individuals of P. abietina, of which 1,903 or $72.1 \%$ of males and 737 females, or $27.9 \%$. This pest caused significant damage in this locality.

KEY WORDS: Hymenoptera, Tenthredinidae, Yelow sticky traps, bionomy, damage of needles. 